\title{
La membrana alveolo-capilar
}

\section{The alveolar-capillary membrane}

\author{
Carmelo Dueñas Castell, MD.(1); Adriana Fortich Salvador, MD. ${ }^{(2)}$; \\ GUILLERMO ORTIZ RUIZ, MD. ${ }^{(3)}$
}

\section{Resumen}

La membrana alveolo-capilar ha sido motivo de múltiples estudios y recientemente se ha avanzado mucho en su papel vital en el intercambio gaseoso y en la modulación inmune ante diversas situaciones clínicas. A continuación se revisan los aspectos más destacados del conocimiento científico actual sobre la membrana alveolo-capilar y su rol en condiciones como el síndrome de dificultad respiratoria aguda y la lesión pulmonar asociada a ventilación mecánica. Se resume, además, la evidencia existente sobre el papel de diversas células y mediadores humorales en la fisiopatología de la membrana alveolo-capilar. Comprender la literatura existente sobre el papel inmunomodulador de la membrana alveolo-capilar y su interacción con células, productos inmunes, receptores, canales y vías de expresión debe facilitar el conocimiento sobre los aspectos fisiopatológicos de dicha membrana y esto a su vez debería redundar en un mejor manejo de los pacientes críticos e impactar en desenlaces clínicos vitales.

Palabras clave: membrana alveolo-capilar, síndrome de dificultad respiratoria aguda, lesión pulmonar asociada a ventilador.

\begin{abstract}
The alveolar-capillary membrane has been the subject of multiple studies. Knowledge of its vital role in gas exchange and in immune modulation in various clinical settings has increased greatly in recent times. We review the most important aspects of current scientific knowledge about the alveolar-capillary membrane and its role in conditions such as the acute respiratory distress syndrome and ventilator-induced lung injury. Current evidence about the role of various cells and humoral mediators in the pathophysiology of the alveolar-capillary membrane is also summarized. Understanding the available literature on the immunomodulating function of the alveolar-capillary membrane, and its interaction with cells, immune products, receptors, channels, and ways of expression, should facilitate knowledge of the pathophysiological aspects of the alveolar-capillary membrane. This, in its turn, should improve the management of critically ill patients and have an impact on vital clinical outcomes.
\end{abstract}

Keywords: alveolar-capillary membrane, acute respiratory distress syndrome, ventilator-induced lung injury

\section{Membrana de intercambio gaseoso}

La membrana alveolo-capilar, en su extensión, cuenta con un arsenal de elementos que a su vez ejercen funciones específicas frente a mecanismos de inflamación y noxas concretas.

En 1842, Addison propuso que el alveolo pulmonar estaba revestido de un epitelio continuo. Durante más de cien años se cuestionó la forma, constitución y función de este epitelio. Los trabajos de Miller, en 1947, y otros posteriores, basados en microscopia electrónica en animales, apoyaron la
(1)Profesor Universidad de Cartagena. Intensivista UCI Gestión Salud, UCI Santa Cruz de Bocagrande. Cartagena, Colombia.

${ }^{(2)}$ Residente III de Medicina Interna, Universidad de Cartagena. Cartagena, Colombia.

${ }^{(3)}$ Jefe postgrado de Medicina Interna, Universidad El Bosque. Jefe UCI Hospital Santa Clara. Profesor Universidad El Bosque. Bogotá, Colombia.

Correspondencia: Carmelo Dueñas Castell. Correo electrónico: crdc2001@gmail.com. Recibido: 01/06/14. Aceptado: 10/06/14. 
teoría de Addison y promovieron la realización de estudios que evaluaran la membrana alveolo-capilar como un todo (1).

En su pionero estudio, Divertie y Brown evaluaron la membrana alveolo-capilar del ser humano en 15 pacientes bajo microscopia electrónica (1). Descubrieron que el alveolo humano normal es una capa continua de citoplasmas celulares con núcleos infrecuentes y pocas mitocondrias. No encontraron poros en el epitelio ni en el endotelio. Además reportaron que entre endotelio y epitelio existen dos membranas basales y entre éstas un espacio intermembranoso con elastina, colágeno y microfibrillas (1).

La membrana alveolo-capilar es una superficie, más o menos homogénea compuesta por un conjunto de estructuras que deben cruzar los gases entre el alveolo y el capilar pulmonar. Está integrada desde el alveolo al capilar (1-6):

- Fina capa de líquido, que cubre el alveolo y contiene el surfactante

- Epitelio alveolar

- Membrana basal alveolar

- Espacio intersticial

- Membrana basal capilar

- Endotelio capilar

A pesar de sus seis capas, tiene un espesor muy delgado, sólo 0,5 micras, en cambio, si al tener en cuenta los 400 a 600 millones de alveolos que posee el ser humano, su superficie es muy amplia, más de 70 metros cuadrados. El oxígeno cruza desde el alveolo al capilar, y el $\mathrm{CO}_{2}$, desde el capilar al alveolo. La difusión se realiza siguiendo los gradientes de presión (3-7).

La $\mathrm{pO}_{2}$ del alveolo es de $104 \mathrm{~mm} \mathrm{Hg}$, mientras que la $\mathrm{pO}_{2}$ en la sangre capilar pulmonar, que regresa de los tejidos periféricos, es solo de $40 \mathrm{~mm} \mathrm{Hg}$. Por tanto, el oxígeno ingresa con una diferencia de presión de $64 \mathrm{~mm} \mathrm{Hg} \mathrm{(3-7).}$

Por el contrario, el $\mathrm{CO}_{2}$, en la sangre capilar pulmonar, tiene una $\mathrm{pCO}_{2}$ de $45 \mathrm{~mm} \mathrm{Hg}$, producto del metabolismo de las células, y en el aire alveolar es menor, solo $40 \mathrm{~mm} \mathrm{Hg}$; por tanto, el $\mathrm{CO}_{2}$ sale desde el capilar hacia el alveolo con una diferencia de presión de $5 \mathrm{~mm} \mathrm{Hg}$. Esta diferencia de gradientes se debe a que la capacidad de difusión del $\mathrm{CO}_{2}$ es veinte veces mayor que la del oxígeno. Todo este proceso se efectúa en menos de medio segundo, tiempo durante el cual la hemoglobina se satura al $100 \%$ y se dirige a la aurícula izquierda a través de las venas pulmonares (3-7).

\section{Membrana como sistema inmunológico}

En las paredes alveolares existe una capa continua de células epiteliales, las cuales son de dos tipos. Las tipo I, son las más abundantes y conforman más del $75 \%$ del total; desempeñan, además, un papel fundamental en el intercambio gaseoso pues son muy delgadas y generalmente impermeables al agua. Por su parte, las células alveolares tipo II son cuboidales y se sitúan en las uniones de los tabiques alveolares; así mismo, poseen gran actividad metabólica, la mitad de la cual está dedicada casi exclusivamente a producir, almacenar y secretar el surfactante. Adicionalmente, contribuyen a la síntesis de fibronectina y demás elementos constitutivos del colágeno (1, 3-9).

De otra parte, en la membrana alveolo-capilar son fundamentales otras células que participan en su funcionamiento normal al tiempo que actúan como mecanismo de defensa e intervienen también en los mecanismos de lesión y reparación de la misma (10).

Hace más de veinte años se comenzó a dar importancia a dicha membrana en la patogénesis y recuperación de la lesión pulmonar, especialmente en la regulación del transporte de sodio, del balance de proteínas y de los fluidos en el pulmón (7-10). Desde entonces, se reportó que la parte epitelial era mucho más resistente a la lesión que el endotelio $(7,8)$. Aparte se han planteado mecanismos para preservar la función de la membrana y para promover la reparación del epitelio alveolar en pacientes con síndrome de dificultad respiratoria aguda (SDRA) (3, 6-10).

Uno de los conceptos centrales acerca de la lesión pulmonar aguda y el SDRA, es la cantidad de elementos que promueven la respuesta inflamatoria, 
representados por una alteración en el equilibrio, que culmina en la expresión de daño epitelial o endotelial (11-15).

Estos cambios encierran alteraciones en el reclutamiento y la actividad de los leucocitos, una expresión inapropiada de citoquinas, mediadores lipídicos y especies reactivas de oxígeno (ROS), y, en consecuencia, producen una activación de las vías de apoptosis, de la cascada de coagulación o de una agregación plaquetaria descontrolada (16).

Usualmente estas vías son activadas tras la exposición a patógenos o sustancias identificadas como potencialmente peligrosas a través de patrones de patógenos o daño (DAMP/PAMP) claramente establecidos por una amplia gama de receptores integrados en un sistema de reconocimiento: los TLR (receptores toll-like), NLR (receptores NOD-like), RLR (receptores RIG-I-Like), receptores de lectina tipo $\mathrm{C}$ y los receptores AIM2 (abscence in melanoma 2-Like) (17-19).

Bajo el sistema de defensa inmunológico existe una expresión de múltiples células que permiten hacer frente a los procesos patológicos (figuras 1 y 2 ).

\section{Macrófagos alveolares}

Forman la primera línea de defensa. Están compuestos por diferentes subgrupos que residen a nivel pulmonar o son reclutados de la circulación en respuesta a un estímulo inflamatorio (20-22). En modelos de experimentación animal se lograron reclutar cierto número de macrófagos alveolares, y se observó que se obtenía una atenuación de la respuesta inflamatoria, antagonizando los receptores de IL-1 (IL-1ra) (23). En otros modelos de daño pulmonar, como neumonía viral, los macrófagos contribuyeron a empeorar aún más el proceso inflamatorio producto de la expresión de ligandos asociados a vías de apoptosis o por expresión de TNF dependiente de p38/MK2 (11, 24, 25). Además, se ha demostrado que los precursores de los macrófagos son capaces de regular el reclutamiento de neutrófilos y la pérdida de las funciones de la barrera alveolo-capilar en el daño pulmonar agudo, asociado con infecciones por gramnegativos, por lo cual se ha propuesto a la depleción de monocitos como potencial blanco terapéutico (10) (figura 1).

Por otro lado, se ha expuesto que la depleción en el sistema monocito/macrófago puede conllevar pérdida de efectos antiinflamatorios importantes y benéficos $(26,27)$.

Esta dicotomía refleja la gran plasticidad funcional de los macrófagos, los cuales han sido agrupados con base en su fenotipo de polarización, dependiendo del contexto del tiempo y el patógeno causal. Por ejemplo, la expresión de un fenotipo de polarización de macrófagos M1 o pro-inflamatorio, versus un fenotipo M2 o anti-inflamatorio, es inducida durante el proceso de reclutamiento en el espacio aéreo o a nivel de los complejos de unión intercelular (28). El estado de polarización de los macrófagos y su capacidad a favor o en detrimento de la membrana alveolo-capilar es, en efecto, inducido por determinantes locales $(29,30)$ y señales moleculares.

\section{Neutrófilos}

A pesar de la importante función inmunológica que cumplen en la erradicación de los procesos infecciosos, las altas concentraciones de los mismos se han asociado con daño de la barrera alveolo-capilar en el contexto de una lesión pulmonar aguda (31) (figura 1).

Los neutrófilos se encuentran en la zona marginal de los capilares alveolares, con el fin de responder dinámicamente frente a una noxa inflamatoria, lo cual incluye interacciones estrechas con los receptores de citoquinas (32) y con moléculas de adhesión endotelial como JAM (del inglés junctional adhesion molecules), ICAM-1 (intracellular adhesion molecule-1), PECAM-1 (platelet endothelial cell adhesion molecule-1) y VCAM-1 (vascular adhesion molecule-1) que están regulados por mediadores inflamatorios tipo TNF (33-35). Una vez reclutados, liberan proteasas, moléculas compuestas de cromatina y sustancias antimicrobianas, las cuales pueden causar daño a nivel epitelial $(36,37)$ y amplificar la señal a partir de un efecto autocrino, determinado por la concentración de CXCL10-CXCR3, lo cual se 
ha descrito en pacientes con infecciones inducidas por el virus de influenza (38) (tablas 1 y 2).

Dentro del conjunto de factores secretados, se encuentran las $\alpha$-defensinas que se liberan de forma abundante en los neutrófilos activados. En estudios con ratones transgénicos, a los cuales se les indujo lesión pulmonar aguda tras la instilación de ácido, se estudió la permeabilidad vascular in vivo. En este estudio, los animales con mayor concentración de $\alpha$-defensina se asociaron con mayor severidad y mayor disrupción de la barrera alveolo-capilar, de ahí que se concluye que la concentración de $\alpha$-defensinas media procesos de lesión pulmonar aguda con pérdida de la función de la membrana alveolo-capilar, sugiriendo la posibilidad de un nuevo blanco de intervención terapéutica (figuras 1 y 2).

De manera contradictoria, datos recientes sugieren que los neutrófilos pueden inducir señales de regeneración inmediata en el epitelio que se ha dañado durante la transmigración, o señales dependientes de elastasa, lo cual contradice el concepto de que los neutrófilos son los principales generadores de daño pulmonar (39).

\section{Plaquetas}

Desempeñan también un papel importante en la homeostasis pulmonar. Se les han atribuido roles esenciales en la defensa del huésped y en la fisiopatología de la sepsis. Las plaquetas expresan TLR, permitiendo ser censadas por las proteínas de unión intercelular, y a través de ello liberan moléculas microbicidas y fagocitan patógenos $(14,40)$. Adicionalmente, modulan la función de las células endoteliales y los leucocitos durante la infección. Esta interacción plaqueta-neutrófilo ha sido descrita como crucial en el reclutamiento alveolar mediado por citoquinas derivadas de plaquetas CCL5, CXCL4 y P-selectina (14). Sin embargo, las plaquetas secretan metabolitos como la IL-1 y tromboxano A2 (TxA2) con el fin de incrementar la actividad bactericida de los neutrófilos, promoviendo así la fase inflamatoria (tablas 1 y 2).

La interacción entre plaquetas, leucocitos y células endoteliales permite resaltar cómo interactúan componentes de la inflamación con agentes de la coagulación para batallar en contra de la infección pulmonar (10). Está descrito que las alteraciones en la coagulación o en las vías fibrinolíticas contribuyen

Tabla 1. Papel de los mediadores Inflamatorios y células del sistema Inmune en la regulación de los procesos inflamatorios a nivel pulmonar.

\begin{tabular}{|ll|}
\hline \multicolumn{1}{|c|}{ Estructura } & \multicolumn{1}{c}{ Función } \\
Macrófagos Alveolares & Primera línea de defensa celular \\
& Atenuación de inflamación por reclutamiento \\
Neutrófilos & Dicotomía por rol proinflamatorio (M1). \\
& $\begin{array}{l}\text { Transmigración } \\
\text { Liberación de sustancias inflamatorias }\end{array}$ \\
Plaquetas & Efecto de regeneración epitelial (tardío) \\
& Liberación de moléculas microbicidas \\
MPK (Protein-kinasa Mitogénica) & Fagocitosis \\
DMT-1 (Divalent Metal Transporter 1) & Modulación de células endoteliales \\
Vía de las Caspasas & MPK-1 efecto protector \\
TRL-4 & MPK-2 efecto proinflamatorio \\
\hline
\end{tabular}


Tabla 2 . Papel de los mediadores No Inflamatorios durante mecanismos de estrés y daño pulmonar.

\begin{tabular}{|c|c|}
\hline Estructura & Función \\
\hline Niveles de $\mathrm{PCO}_{2}$ & $\begin{array}{l}\text { Rol anti-inflamatorio (controversial) } \\
\text { Reducción de estrés oxidativo (controversial) } \\
\text { Alteración de inmunidad innata, función de macrófagos y barrera } \\
\text { alveolar }\end{array}$ \\
\hline Oxido Nítrico & $\begin{array}{l}\text { Activación de GMPC (benéfico) } \\
\text { Formación de peroxinitrito (efecto negativo) }\end{array}$ \\
\hline Proteasoma & $\begin{array}{l}\text { Regula expresión y porteóstasis de moléculas inflamatorias, } \\
\text { proteínas de unión y surfactante }\end{array}$ \\
\hline Claudinas (27 subtipos) & Elementos anti-disrupción de la barrera epitelial \\
\hline Ocludinas & $\begin{array}{l}\text { Rol regulador y posible inmunomodulador } \\
\text { Asociado con transmigración de neutrófilos }\end{array}$ \\
\hline Zonula Ocludens & Estructura y estabilidad de la membrana apical celular \\
\hline Tricelulina & Unión celular \\
\hline JAM (junctional Adhesion Molecule) & Regulador del paso paracelular \\
\hline CAR (Cosackie Adenovirus Receptor) & $\begin{array}{l}\text { Expresión en la vía aérea } \\
\text { Mecanismo en inflamación en estudio }\end{array}$ \\
\hline b-Catenina & Transmigración de neutrófilos \\
\hline Proteínas de Polaridad & Morfogénesis y sustento de la polarización de la membrana \\
\hline Fosfoproteína estimulada por vasodilatador (VASP) & Reorganización de Citosqueleto durante estrés pulmonar. \\
\hline Glucocalix & Regulador de la integridad de la Barrera \\
\hline
\end{tabular}

a la patogénesis de la lesión pulmonar aguda (41, 42) y a la hipertensión pulmonar asociada (43).

\section{Mediadores inflamatorios}

Adicionalmente, hay una variedad de mediadores inflamatorios y vías de señalización que favorecen la progresión del daño pulmonar. En particular, el MPK-2, un inhibidor endógeno de la vía de señalización de la protein-kinasa mitogénica activada o MAPK, ha sido identificado como posible blanco terapéutico en lesión pulmonar aguda asociada a neumonía, ya que ante su ausencia -murinos mkp2 null- se ha demostrado una respuesta proinflamatoria atenuada (44). Por el contrario, MKP-1, activador de la vía MAPK, ha tenido efecto protector contra lesión pulmonar aguda inducida por ventilador (45). Moléculas como el ácido lisofosfatídico, el cual es un fosfolípido bioactivo, ejercen un rol importante en la lesión pulmonar aguda, induciendo la liberación de citoquinas y mediadores lipídicos (46) (tablas 1 y 2).
Otros agentes pro-inflamatorios (47) demostraron que la inflamación pulmonar puede ser modificada a través de la concentración del transportador de metales divalentes tipo 1-DMT1 (divalent metal transporter 1) o por el estado del hierro sérico. Animales con déficit de DMT-1 mostraron incremento del daño pulmonar tras la instilación de LPS (lipopolisacáridos).

Así mismo, la deleción de la caspasa-1 y la inhibición de la vía de las caspasas, fue documentada como efecto protector en modelos animales usando diferentes LPS (10). Se ha descrito el incremento en los niveles de IL-18 al inhibir estas vías, por lo cual niveles bajos del mismo se han asociado con progresión del daño pulmonar (48).

Finalmente, los TLR4, en conjunto con el estrés oxidativo y los fosfolípidos oxidados, se exponen como conductores cruciales en diferentes modelos de daño pulmonar agudo (49-51).

Revista Colombiana de Neumología Vol 26 No 3 | 2014 


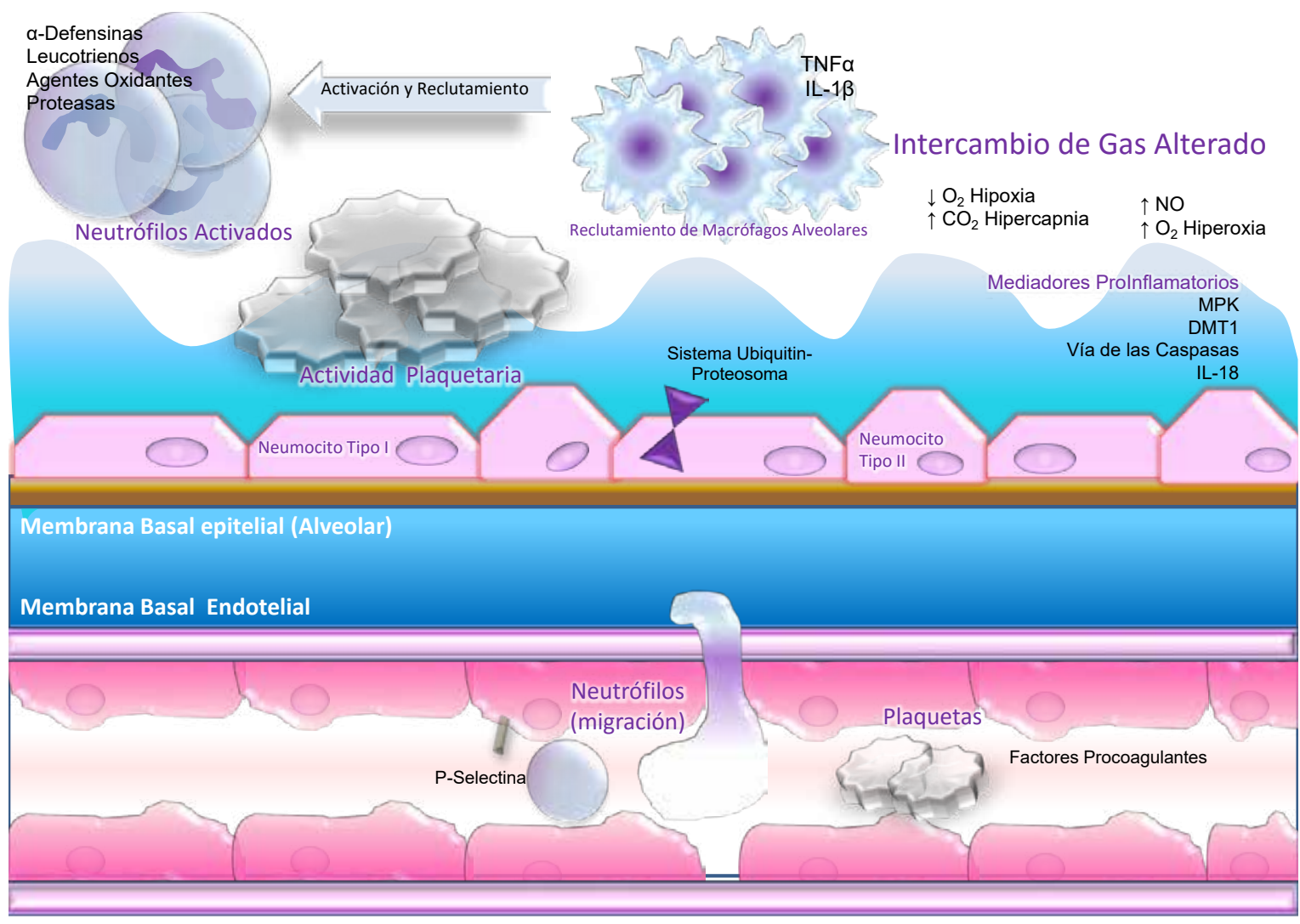

Figura 1. Representación esquemática de los mecanismos celulares y bioquímicos, implicados en la patogénesis de la lesión pulmonar aguda, en donde está incluidos, los macrófagos, neutrófilos activados, plaquetas y mediadores de la inflamación. TNF-a: Factor de necrosis tumoral $-\alpha$. IL-1 $\beta$ : Interleucina $1 \beta . \mathrm{CO}_{2}$ : Dióxido de carbono. $\mathrm{O}_{2}$ : Oxígeno. NO: Oxído nítrico. MPK: Mitogenic Protein Kinase. DMT-1: Divalent Metal-transporter type 1.

\section{Mediadores no inflamatorios}

La hipoxia severa define la lesión pulmonar aguda y cumple un papel preponderante. En pacientes con SDRA, la hipoxia alveolar contribuye a la patogénesis y a la progresión del daño (52), ejerciendo un efecto proinflamatorio y amplificando el daño tanto alveolar, como de las células endoteliales (53). Además, se ha descrito que la hipoxia altera los complejos de unión celular (54) y regula el transporte de sodio intersticial $(55,56)$, provocando una acumulación de líquidos y estableciendo el edema pulmonar. Esto promueve el uso de altas fracciones de oxígeno inspirado, e induce, en consecuencia, estados de hiperoxia, que, por ende, dan lugar a la formación de radicales de oxígeno reactivos $(57,58)$ y permiten continuar con la activación del inflasoma (59) (tablas 1 y 2).

A causa de una ventilación protectora, en muchos de estos casos se manejan bajos volúmenes corrientes que desencadenan niveles altos de $\mathrm{CO}_{2}$, dando lugar a estados de hipercapnia permisiva. El papel de esta última en SDRA, es altamente controversial (60-62).

A pesar de que los altos niveles de $\mathrm{PCO}_{2}$ tienen propiedades anti-inflamatorias y reducen el estrés oxidativo $(61,63)$, contradictoriamente también parecen alterar la inmunidad innata (63), la función de macrófagos (64), la función de la barrera alveoloepitelial $(65,66)$ y la capacidad de transporte $(67)$, 


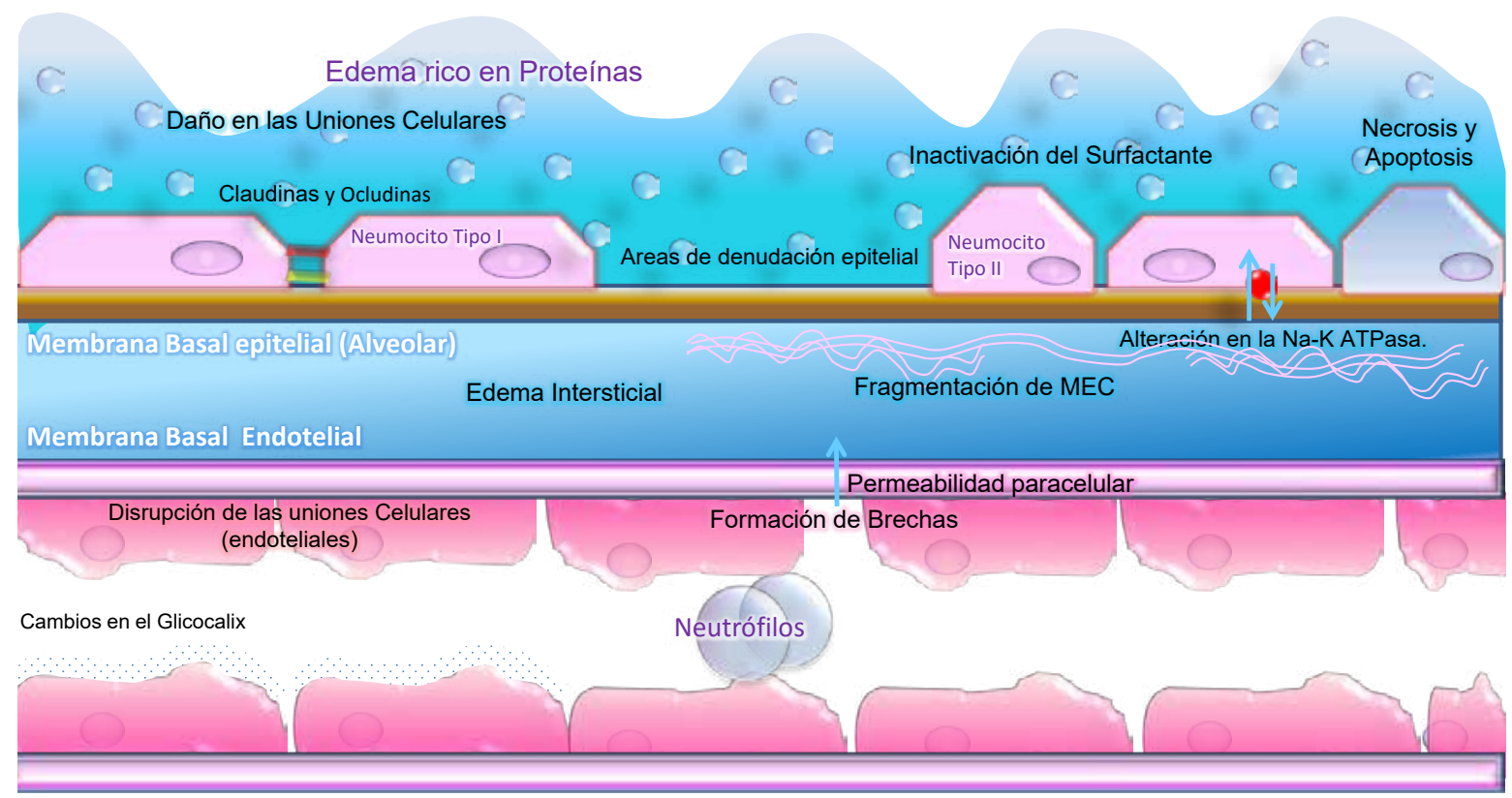

Figura 2. Representación esquemática de los cambios a nivel de la barrera alveolo-capilar en la lesión pulmonar aguda. MEC: Matriz extracelular.

generando desenlaces adversos en el contexto de una lesión pulmonar aguda inducida por Pseudomonas (68) (tabla 2).

Por tanto, ya que la hipoxia, la hiperoxia y la hipercapnia no pueden prevenirse muchas veces en el SDRA, se han planteado propuestas para impactar la concentración de $\mathrm{O}_{2}$ y $\mathrm{CO}_{2}$ a nivel molecular a favor de un mejor intercambio gaseoso.

Otro efecto importante, en cuanto a gases, es la concentración de óxido nítrico, el cual tiene un papel tanto protector como lesivo, en la lesión pulmonar aguda; dependiendo del sitio de acción e interacción. Tradicionalmente, sus efectos benéficos se relacionan con la activación de la guanilato ciclasa, incrementando la producción de GMP cíclico, la cual atenúa la señal de $\mathrm{Ca}_{2}$ endotelial previniendo la formación de brechas paracelulares. Entretanto, su efecto negativo se encuentra en relación con la formación de peroxinitrito (ONOO) en ausencia de superóxido o proteínas de S-nitrosilación (69) (tabla 2).
La homeostasis proteica es regulada por múltiples procesos celulares que incluyen síntesis, almacenamiento, liberación, disgregación y degradación. Estos procesos se reúnen en el término colectivamente empleado "proteostasis" (70). El componente principal de este proceso es el sistema ubiquitínproteasoma (UPS), que desempeña un papel crítico frente a varios mecanismos de producción de daño pulmonar agudo $(71,72)$, los cuales incluyen la expresión de moléculas de respuesta inflamatoria (73), proteínas de unión (74), modificación de la función del surfactante y actividad de transportadores de sodio responsables de filtrar el edema alveolar (75, 76). Estudios recientes con inhibidores de proteasoma, como bortezomib, el cual ha sido aprobado para el tratamiento de mieloma múltiple y linfoma del manto, han demostrado prevenir la fibrosis posdaño pulmonar agudo, estableciendo una posibilidad terapéutica en estos pacientes (77) (tabla 2).

De igual forma, la membrana alveolo-capilar puede ser blanco de estímulos estresores. Se ha 
encontrado que altas concentraciones de $\mathrm{CO}_{2}$, conducen también a un daño mediado por disfunción mitocondrial (78). Esto se suma a que durante los procesos de sepsis los metabolitos de óxido nítrico producen efecto e inducen disfunción a nivel de las mitocondrias. Lo anterior genera depleción de las concentraciones de ATP e incrementa las de lactato, producto de procesos de respiración anaerobia que, a su vez, alteran la función de las Na-K ATPasas desencadenando edema pulmonar.

Se ha documentado, también, daño del ADN mitocondrial $(\mathrm{ADNm})$ que conlleva disfunción de la membrana alveolar (79), y por ende se ha sostenido como blanco terapéutico el uso de antioxidantes que permitan interferir con la lesión a nivel de las vías mitocondriales.

\section{Lipopolisacáridos}

Recientemente se ha descrito que los lipopolisacáridos (LPS) podrían activar a los TRPV1 (del inglés transient receptor potential vanilloid 1), que estimulan vías proapoptóticas mediadas a través de la expresión de la proteína Gadd153 a nivel del retículo endoplasmático incitando a las células a una muerte celular y a estados de citotoxicidad (80).

\section{Proteínas de unión celular}

Mantienen la integridad de la membrana alveolo-capilar. Las uniones estrechas, son componentes intra y extracelulares, y se clasifican en tres subtipos (118): primero los miembros de la familia de las claudinas, en segunda instancia las uniones estrechas asociadas con miembros de la familia MARVEL y por último las proteínas similares a inmunoglobulinas (immunoglobulin-like proteins), como las moléculas de adhesión a unión y el receptor del adenovirus Coxsackie (124).

Las E-cadherinas y los miembros de la familia nectina, representan las mayores proteínas transmembrana a nivel de las uniones epiteliales (125).

Las proteínas transmembrana de la familia de las claudinas son constituyentes primarios de la membrana; fueron descubiertas en 1998 por Tsukita y colegas, quienes describieron la claudina-1 (126). Desde entonces se han identificado 27 tipos de claudinas. Éstas cuentan con cuatro enlaces moleculares, una corta porción $\mathrm{N}$-terminal y una larga porción C-terminal con dominio citoplasmático y dos asas extracelulares. La agregación heterotípica, en especial de la claudina-3, es crucial para la interacción claudina-claudina. Estas se encuentran ampliamente categorizadas en dos grupos: primero, algunas claudinas incrementan la permeabilidad paracelular, las cuales son conocidas como formadoras de poros, y en segunda instancia están las claudinas que interactúan de forma homo- o heterotópica con el fin de promover la integridad de la barrera (118).

Las claudinas se encuentran distribuidas de diferentes maneras a lo largo del árbol traqueobronquial (127-128). En un estudio se documentó la expresión de claudinas: $-1,-3,-4,-5$ y -7 , las cuales diferían en la localización celular (membrana apical versus lateral) (127), mientras que en otro ensayo documentaron una intensa actividad de la claudina -2 , así como de las claudinas -1, -3, -4 y -7 (129).

La caludina-3 se expresa a lo largo de la vía aérea superior a nivel de las células ciliadas y los neumocitos tipo II, y funciona como elemento anti-disrupción de la función de barrera epitelial (130). La claudina -4 , por su parte, ha emergido como elemento de respuesta protector en el contexto de daño pulmonar agudo; sin embargo, su rol aún no se encuentra completamente esclarecido (118). Ambas, la claudina -3 y -4, son blancos de la exotoxina de Clostridium perfringes (131), lo cual podría ser fundamento para establecer un plan terapéutico basado en terapia génica (118). Pese a que la claudina-5 fue detectada en muestras de vía aérea, no lo fue en modelos in vitro de lesión pulmonar aguda, en donde predominó la expresión de las claudinas -1 y -4. (132). Se ha descrito recientemente que la claudina-5 cumple un rol protector y es expresada a nivel de células endoteliales microvasculares durante la infección por los virus de influenza y VIH (virus de inmunodeficiencia adquirida) (133).

La variante claudina -18.2 se ha documentado específicamente a nivel pulmonar, y ha sido implicada 
en la integridad y el mantenimiento de la barrera alveolar, en modelos de daño pulmonar agudo (134).

Estas proteínas son blanco de procesos de estrés oxidativo, de ahí que cualquier disbalance que incremente la concentración en la producción de especies reactivas de oxígeno puede contribuir a lesión pulmonar aguda (82-84).

Tanto las claudinas como las ocludinas y las proteínas de adhesión endotelial (E-caderinas) son objetivos frente a estímulos patológicos (85-87) y al convertirse en disfuncionales perpetúan el proceso de daño pulmonar.

Las ocludinas fueron descritas antes que las claudinas por Furuse y colegas, mientras que caracterizaban anticuerpos monoclonales que reconocieran las uniones estrechas a nivel de los hepatocitos (135). Las ocludinas conservan un dominio MARVEL, el cual consiste en cuatro segmentos hidrofóbicos y los segmentos $-\mathrm{N}$ y $-\mathrm{C}$ terminal que son intracelulares y se encuentran sujetos a numerosas modificaciones post-translacionales, lo cual se cree, podría afectar la interacción con otros componentes del complejo de adherencia celular (136).

Tras dos décadas de investigación, la función de las ocludinas permanece enigmática. En algunos modelos con murinos Ocludin-null, se ha documentado que la función de barrera epitelial, a pesar de esta ausencia, permanece intacta, por lo cual se sugiere que las ocludinas podrían ejercer solo un rol regulador (118). Sin embargo, Vam Itallie y colegas, reportaron un incremento en la expresión de ocludina a través de la inducción por las citoquinas interferón gamma (INF- $\gamma 1$ ) y factor de necrosis tumoral- $\alpha$ (TNF- $\alpha$ ) (137), lo cual sugiere un posible rol en cuanto a inmunomodulación. Adicionalmente, a través de estudios con $\mathrm{H}_{2} \mathrm{O}_{2}$, se documentó que existe una disrupción en la función de barrera de las ocludinas, sugiriendo una alta sensibilidad a los cambios en el estado redox celular (118).

Se ha descrito de forma emergente, que las ocludinas cumplen con un papel en la migración celular inmune, en especial, en la migración transepitelial de los neutrófilos (138). Huber y colegas describieron que la migración de los neutrófilos a través de la barrera epitelial era regulada por el dominio N-terminal de la ocludina, independientemente de la permeabilidad paracelular al manitol (138).

\section{Zonula ocludens}

Es otra de las estructuras que hacen parte del complejo de adhesión celular.

La zonula ocludens-1 (ZO-1) fue identificada por primera vez en 1986 como estructura de unión fuerte epitelial (139) y es conocida como miembro de la familia de las guanilato-quinasas asociadas a membrana (140-141), al igual que la ZO-2 (142) y la ZO-3 (143). A nivel tisular, estas proteínas se expresan de diferentes maneras y contienen un volumen numeroso de dominios, capaces de establecer interacción proteína-proteína con otros componentes de adherencia celular, con el citoesqueleto de actina y con otras moléculas de señalización (118). Por ello, las proteínas $\mathrm{ZO}$ son componentes importantes del andamiaje celular ya que ayudan a mantener y estabilizar la membrana apical. La función de estas proteínas aún no es clara; sin embargo, en algunos contextos se ha descrito que pueden actuar como represores transcripcionales (144). En estudios con murinos, la deficiencia de la ZO-1 y ZO-2 resultó en letalidad total de los embriones, mientras que murinos con deficiencia de ZO-3 fueron aparentemente normales, reflejando el hecho que la ZO-1 y ZO-2 se expresan en células endoteliales y epiteliales, mientras que la ZO-3 se restringe a células epiteliales, y su función podría ser compensada con otros miembros del complejo de adherencia celular $(145,146)$.

\section{Otras moléculas}

Contribuyen a la unión intercelular, en primera instancia, las proteínas de la familia MARVEL como la tricelulina, la cual se expresa ampliamente en oído interno, piel, estómago y células epiteliales nasales (147); sin embargo, a pesar de expresarse también en células de la línea mieloide, no se conoce su expresión a nivel pulmonar y requiere mayores estudios (118).

Por otra parte, existen los miembros de la familia de inmunoglobulinas en donde se encuentran las 
moléculas de adhesión a unión (por sus siglas en Inglés, JAM junctional adhesion molecule) y el receptor del adenovirus Coxsackie (o CAR, sigla en Inglés para Coxsackie adenovirus receptor) (124). Las moléculas de adhesión a unión se expresan a nivel de la superficie basolateral celular, las cuales pueden promover el paso a reovirus (148); no obstante, su rol respecto a la permeabilidad global y el reclutamiento celular no ha sido investigado sistemáticamente (118). En cuanto al receptor de adenovirus Coxsackie, existen múltiples isoformas que se expresan a nivel de la vía aérea en localización celular, tanto apical como basolateral; sin embargo, su función en relación con la inmunomodulación, aún permanece como blanco de estudio.

Otras moléculas como la b-catenina, se encuentran envueltas en la transmigración de neutrófilos a través de las células alveolo-epiteliales; ésta, por si misma es capaz de inducir disfunción suficiente, y ejercer, por tanto, un rol importante en el mantenimiento de la homeostasis paracelular.

\section{Proteínas de polaridad}

Son esenciales para la morfogénesis y el sustento de la polarización apical versus basolateral. En la actualidad estas proteínas son un área de investigación en expansión (149), pero se requieren más estudios para establecer su función.

\section{Fosfoproteína estimulada por vasodilatador}

Es una proteína encargada de la reorganización del cito-esqueleto durante procesos de estrés pulmonar, pues reduce las fibras de estrés y mantiene las propiedades fisiológicas de la barrera $(150,151)$. A través de estudios en murinos VASP- null, se ha descrito que existe un mecanismo regulador mediado por VASP, durante los procesos de daño pulmonar agudo. En éstos se documentó que la severidad del proceso inflamatorio a nivel pulmonar fue mayor (152).

\section{Conexinas}

La función de la barrera endotelial también es regulada por miembros de la familia de las conexinas $(\mathrm{Cx})$, como la $\mathrm{Cx} 43, \mathrm{Cx} 40$ y Cx37 que forman uniones complejas en los canales de unión endotelial, permitiendo el paso de pequeñas moléculas y solutos selectivos $(91,92)$. Por ejemplo, la conexina $\mathrm{Cx} 43$ se ha relacionado con la regulación del paso de $\mathrm{Ca}_{2}$ a través del espacio interendotelial, que a su vez promueve la actividad del receptor de adhesión leucocitaria y P-selectina, y, por ende, contribuye a la propagación de la inflamación (93).

La inhibición de la Cx43 con el inhibidor de péptidos Gap27 previene el incremento de la permeabilidad endotelial después de la instilación de ácido a nivel alveolar, lo cual confirma la importancia de los canales de unión celular en la generación y expansión de daño pulmonar (94).

El estado de hiperpermeabilidad endotelial se traduce en disrupción de la membrana al producir una retracción de las células del endotelio y permitir la formación de brechas paracelulares.

Esta cascada de eventos está relacionada con la activación de la calmodulina y la fosforilación de las cadenas de miosina, lo cual facilita la reorganización del citoesqueleto y conduce a cambios en la configuración de la morfología extracelular (88-90).

\section{Glucocálix}

Es otro componente de la barrera alveolo-capilar, que ha sido reconocido como regulador de la integridad de la barrera. Está constituido por una capa laminar dinámica de glicoproteínas, glicolípidos, proteoglicanos y glicosaminoglicanos $(95,96)$. Se ha descrito que adicionalmente el glucocálix ejerce su efecto a través de señales de mecanotransducción (97) y que la depleción en la concentración de ácido siálico, que se encuentra en las cadenas de carbohidratos, contribuye significativamente a generar cambios en la carga eléctrica de las superficies celulares permitiendo que se desencadene una disfunción en la barrera endotelial (49), demostrando así la importancia de la matriz extracelular.

\section{Integrinas}

Los heterodímeros que conectan las células endoteliales con la matriz extracelular se conocen 
como integrinas, las cuales sensan cambios en la matriz, regulan la organización del citoesqueleto y desempeñan un papel significativo en la señalización. Una alteración en los complejos de adhesión local, compuesto por las integrinas, genera una disrupción de la barrera endotelial (98). El estrés oxidativo, inducido por el cigarrillo es capaz de desencadenar una alteración en la actividad kinasa de las moléculas de adhesión focal, lo cual incrementa la permeabilidad endotelial in vivo (99). Estos efectos fueron atribuidos a la actividad RhoA GTPasa.

El edema pulmonar es el marcador cardinal del SDRA (100). La pérdida en la estructura y función de la barrera alveolo-capilar, no solo permite el incremento en la filtración de líquido rico en proteínas al espacio intersticial, sino que también hace menos probable el proceso de reparación del epitelio (101).

\section{Canales de sodio}

Se ha descrito que los canales de sodio son elementos fundamentales en la regulación del edema, y que una función correcta de los mismos podría resolver este evento de forma vectorial (102-106). Aparentemente, se requiere la subunidad de $\mathrm{Na}-\mathrm{K}$ ATPasa para la polarización celular y formación de uniones intercelulares, esenciales en la estabilización de la barrera (107-110).

Las fases agudas de la lesión pulmonar aguda se caracterizan por inflamación, daño celular, apoptosis o necrosis y formación subsecuente de edema pulmonar. Si el paciente sobrevive a la fase aguda, continúa a la fase fibroproliferativa, en la que existe un incremento en la multiplicación de los neumocitos, fibroblastos y miofibroblastos que se depositan a nivel de la matriz extracelular (111).

Los receptores para los productos avanzados de la glicosilación son agentes cardinales. Al estar alterados, median el incremento en la migración celular y la profilefración (112-116); además, se ha documentado que bajo estas circunstancias interactúan con los CD 44 y las fibras de actina, y ocasionan una pérdida en la adhesión que conduce a un fenotipo invasivo a la matriz extracelular (117).

\section{Conclusiones}

Esta revisión pretende resumir la literatura existente sobre el papel de la membrana alveolo-capilar como modulador inmune y su interacción con células, productos inmunes, receptores, canales y vías de expresión de diversas respuestas. El conocimiento exacto e integrado de todo lo anterior, debe favorecer una mejor comprensión del papel de la membrana alveolo-capilar, su importancia fisiológica y en condiciones patológicas y, más importante aún, la posible utilidad en la prevención y manejo de la lesión pulmonar, el SDRA y la generación de falla orgánica múltiple. Los autores consideran que todo lo precedente debería redundar en un manejo óptimo de los pacientes críticos y un impacto de los desenlaces clínicos vitales.

\section{Bibliografía}

1. Matthew B, Divertie MB, Brown AL Jr. The fine structure of the normal human alveolocapillary membrane. JAMA.1964;187:938-41.

2. Ghoreyeb AA, Karsner HT. A study of the relation of pulmonary and bronchial circulation. J Exp Med. 1913;18:500-6.

3. Fhari. A theorical analysis of the alveolar-arterial $\mathrm{O} 2$ difference with special reference to the distribution effect. J Appl Physiol. 1955;7:599-602.

4. Martínez Guerra ML, Fernández Bonett P, Lupi Herrera E. Alveolar arterial $\mathrm{O} 2$ gradient in patients with cardiopulmonary pathology. Its study at rest with respiration of environmental air. Arch Inst Cardiol Mex. 1979;49(6):1055-65.

5. Finch CA, Lenfant C. Oxygen transport in man. $\mathrm{N}$ Engl J Med. 1972;286:407-11.

6. Elliott CG, Morris AH, Cengiz M. Pulmonary function and exercise gas exchange in survivors of adult respiratory distress syndrome. Am Rev Respir Dis. 1981;123(5):492-5.

7. Borok Z. Alveolar epithelium: beyond the barrier. Am J Respir Cell Mol Biol. 2014;50(5):853-6.

8. Matthay MA, Folkesson HG, Campagna A, Kheradmand F: Alveolar epitelial barrier and acute lung injury. New Horiz.1993;1:613-22.

9. Budinger GR, Sznajder JL. The alveolar-epithelial barrier: a target for potential therapy. Clin Chest Med. 2006;27:65569.

10. Herold S, Gabrielli NM, Vadász I. Novel concepts of acute lung injury and alveolar-capillary barrier dysfunction. Am J Physiol Lung Cell Mol Physiol. 2013;305:665-1.

11. Hogner K, Wolff T, Pleschka S, Plog S, Gruber AD, Kalinke $\mathrm{U}$, et al. Macrophage-expressed IFN- $\gamma$ contributes to apop- 
totic alveolar epithelial cell injury in severe influenza virus pneumonia. PLoS Pathog 2013;9: e1003-188,.

12. Hosakote YM, Komaravelli N, Mautemps N, Liu T, Garofalo RP, Casola A. Antioxidant mimetics modulate oxidative stress and cellular signaling in airway epithelial cells infected with respiratory syncytial virus. Am J Physiol Lung Cell Mol Physiol. 2012;303:L991-1000.

13. Lipke AB, Matute-Bello G, Herrero R, Wong VA, Mongovin SM, Martin TR. Death receptors mediate the adverse effects of febrile-range hyperthermia on the outcome of lipopolysaccharide-induced lung injury. Am J Physiol Lung Cell Mol Physiol. 2011;301:L60-70.

14. Seeley EJ, Matthay MA, Wolters PJ. Inflection points in sepsis biology: from local defense to systemic organ injury. Am J Physiol Lung Cell Mol Physiol. 2012;303:L355-63.

15. van den Berg E, van Woensel JB, Bos AP, Bem RA, Altemeier WA, Gill SE, et al. Role of the Fas/FasL system in a model of RSV infection in mechanically ventilated mice. Am J Physiol Lung Cell Mol Physiol. 2011;301:L451-60.

16. Matthay MA, Ware LB, Zimmerman GA. The acute respiratory distress syndrome. J Clin Invest. 2012;122:2731-40.

17. Opitz B, van Laak V, Eitel J, Suttorp N. Innate immune recognition in infectious and noninfectious diseases of the lung. Am J Respir Crit Care Med. 2010;181:1294-309.

18. Wu $\mathrm{Q}$, Jiang $\mathrm{D}$, Minor MN, Martin RJ, Chu HW. In vivo function of airway epithelial TLR2 in host defense against bacterial infection. Am J Physiol Lung Cell Mol Physiol. 2011;300:L579-86.

19. Wu W, Patel KB, Booth JL, Zhang W, Metcalf JP. Cigarette smoke extract suppresses the RIG-I-initiated innate immune response to influenza virus in the human lung. Am J Physiol Lung Cell Mol Physiol. 2011;300:L821-30.

20. D'Alessio FR, Tsushima K, Aggarwal NR, Mock JR, Eto Y, Garibaldi BT, et al. Resolution of experimental lung injury by monocyte-derived inducible nitric oxide synthase. J Immunol 2012;189:2234-45.

21. Herold S, Mayer K, Lohmeyer J. Acute lung injury: how macrophages orchestrate resolution of inflammation and tissue repair. Front Immunol. 2011;2:65.

22. Liang J, Jung Y, Tighe RM, Xie T, Liu N, Leonard M, et al. A macrophage subpopulation recruited by $\mathrm{CC}$ chemokine ligand-2 clears apoptotic cells in noninfectious lung injury. Am J Physiol Lung Cell Mol Physiol. 2012;302:L933-40.

23. Herold S, Tabar TS, Janssen H, Hoegner K, Cabanski M, LeweSchlosser P, et al. Exudate macrophages attenuate lung injury by the release of IL-1 receptor antagonist in gram-negative pneumonia. Am J Respir Crit Care Med. 2011;183:1380-90.

24. Bem RA, Domachowske JB, Rosenberg HF. Animal models of human respiratory syncytial virus disease. Am J Physiol Lung Cell Mol Physiol. 2011;301:L148-56.

25. O'Dea KP, Dokpesi JO, Tatham KC, Wilson MR, Takata M. Regulation of monocyte subset proinflammatory responses within the lung microvasculature by the p38 MAPK/MK2 pathway. Am J Physiol Lung Cell Mol Physiol. 2011;301:L812-21.

26. Dhaliwal K, Scholefield E, Ferenbach D, Gibbons M, Duffin R, Dorward DA, et al. Monocytes control second-phase neutrophil emigration in established lipopolysaccharide induced murine lung injury. Am J Respir Crit Care Med. 2012;186:514-24.

27. Su X. Leading neutrophils to the alveoli: who is the guider? Am J Respir Crit Care Med. 2012;186:472-3.

28. Bhattacharya M, Su G, Su X, Oses-Prieto JA, Li JT, Huang $\mathrm{X}$, et al. IQGAP1 is necessary for pulmonary vascular barrier protection in murine acute lung injury and pneumonia. Am J Physiol Lung Cell Mol Physiol. 2012;303:L12-L19.

29. Nelson MP, Christmann BS, Dunaway CW, Morris A, Steele C. Experimental Pneumocystis lung infection promotes M2a alveolar macrophage- derived MMP12 production. Am J Physiol Lung Cell Mol Physiol. 2012;303:L469-75.

30. Nguyen HA, Rajaram MV, Meyer DA, Schlesinger LS. Pulmonary surfactant protein A and surfactant lipids upregulate IRAK-M, a negative regulator of TLR-mediated inflammation in human macrophages. Am J Physiol Lung Cell Mol Physiol. 2012;303:L608-16.

31. Lee WL, Downey GP. Neutrophil activation and acute lung injury. Curr Opin Crit Care. 2001;7: 1-7.

32. Zamjahn JB, Quinton LJ, Mack JC, Frevert CW, Nelson S, Bagby GJ. Differential flux of macrophage inflammatory protein-2 and cytokine-induced neutrophil chemo attractant from the lung after intrapulmonary delivery. Am J Physiol Lung Cell Mol Physiol. 2011;301:L568-74,.

33. Bertok S, Wilson MR, Dorr AD, Dokpesi JO, O'Dea KP, Marczin N, Takata M. Characterization of TNF receptor subtype expression and signaling on pulmonary endothelial cells in mice. Am J Physiol Lung Cell Mol Physiol. 2011;300:L781-9.

34. Herold S, von Wulffen W, Steinmueller M, Pleschka S, Kuziel WA, Mack M, et al. Alveolar epithelial cells direct monocyte transepithelial migration upon influenza virus infection: impact of chemokines and adhesion molecules. J Immunol. 2006;177:1817-24.

35. Lakshmi SP, Reddy AT, Naik MU, Naik UP, Reddy RC. Effects of JAM-A deficiency or blocking antibodies on neutrophil migration and lung injury in a murine model of ALI. Am J Physiol Lung Cell Mol Physiol. 2012;303:L758-66.

36. Narasaraju T, Yang E, Samy RP, Ng HH, Poh WP, Liew AA, et al. Excessive neutrophils and neutrophil extracellular traps contribute to acute lung injury of influenza pneumonitis. Am J Pathol. 2011;179:199-210.

37. Saffarzadeh M, Juenemann C, Queisser MA, Lochnit G, Barreto G, Galuska SP, et al. Neutrophil extracellular traps directly induce epithelial and endothelial cell death: a predominant role of histones. PloS One. 2012;7:e32366.

38. Ichikawa A, Kuba K, Morita M, Chida S, Tezuka H, Hara H, et al. CXCL10-CXCR3 enhances the development of neutrophilmediated fulminant lung injury of viral and nonviral origin. Am J Respir Crit Care Med. 2013;187:65-77.

39. Zemans RL, Briones N, Campbell M, McClendon J, Young 
SK, Suzuki T, et al. Neutrophil transmigration triggers repair of the lung epithelium via _-catenin signaling. Proc Natl Acad Sci USA. 2011;108:15990- $\overline{5}$.

40. Jenne CN, Urrutia R, Kubes P. Platelets: bridging hemostasis, inflammation, and immunity. Int J Lab Hematol. 2013;35:254-61.

41. Idell S, James KK, Levin EG, Schwartz BS, Manchanda N, Maunder RJ, et al. Local abnormalities in coagulation and fibrinolytic pathways predispose to alveolar fibrin deposition in the adult respiratory distress syndrome. J Clin Invest. 1989;84:695-705.

42. Komissarov AA, Stankowska D, Krupa A, Fudala R, Florova G, Florence J, et al. Novel aspects of urokinase function in the injured lung: role of _2- macroglobulin. Am J Physiol Lung Cell Mol Physiol. 2012;303:L1037-45.

43. Price LC, McAuley DF, Marino PS, Finney SJ, Griffiths MJ, Wort SJ. Pathophysiology of pulmonary hypertension in acute lung injury. Am J Physiol Lung Cell Mol Physiol. 2012;302:L803-15.

44. Cornell TT, Fleszar A, McHugh W, Blatt NB, Le Vine AM, Shanley TP. Mitogen-activated protein kinase phosphatase 2, MKP-2, regulates early inflammation in acute lung injury. Am J Physiol Lung Cell Mol Physiol. 2012;303:L251-8.

45. Park MS, He Q, Edwards MG, Sergew A, Riches DW, Albert RK, et al. Mitogen-activated protein kinase phosphatase-1 modulates regional effects of injurious mechanical ventilation in rodent lungs. Am J Respir Crit Care Med. 2012;186:72-81.

46. Zhao J, He D, Su Y, Berdyshev E, Chun J, Natarajan V, Zhao Y. Lysophosphatidic acid receptor 1 modulates lipopolysaccharide-induced inflammation in alveolar epithelial cells and murine lungs. Am J Physiol Lung Cell Mol Physiol. 2011301:L547-56.

47. Kim J, Molina RM, Donaghey TC, Buckett PD, Brain JD, Wessling-Resnick M. Influence of DMT1 and iron status on inflammatory responses in the lung. Am J Physiol Lung Cell Mol Physiol. 2011;300:L659-65.

48. Dolinay T, Kim YS, Howrylak J, Hunninghake GM, An CH, Fredenburgh L, et al. Inflammasome regulated cytokines are critical mediators of acute lung injury. Am J Respir Crit Care Med. 2012;185:1225-34.

49. Imai Y, Kuba K, Neely GG, Yaghubian-Malhami R, Perkmann $\mathrm{T}$, van Loo $\mathrm{G}$, et al. Identification of oxidative stress and tolllike receptor 4 signaling as a key pathway of acute lung injury. Cell. 2008;133:235-49.

50. Shirey KA, Lai W, Scott AJ, Lipsky M, Mistry P, Pletneva LM, et al. The TLR4 antagonist eritoran protects mice from lethal influenza infection. Nature. 2013;497:498-502.

51. Westphalen K, Monma E, Islam MN, Bhattacharya J. Acid contact in the rodent pulmonary alveolus causes proinflammatory signaling by membrane pore formation. Am J Physiol Lung Cell Mol Physiol. 2012;303: L107-16.

52. Frohlich S, Boylan J, McLoughlin P. Hypoxia-induced inflammation in the lung: a potential therapeutic target in acute lung injury? Am J Respir Cell Mol Biol. 2013;48:271-9.
53. Eltzschig HK, Carmeliet P. Hypoxia and inflammation. N Engl J Med. 2011;364:656-65.

54. Caraballo JC, Yshii C, Butti ML, Westphal W, Borcherding JA, Allamargot $\mathrm{C}$, et al. Hypoxia increases transepithelial electrical conductance and reduces occludin at the plasma membrane in alveolar epithelial cells via PKC__ and PP2A pathway. Am J Physiol Lung Cell Mol Physiol. 2011;300: L569-78.

55. Dada LA, Chandel NS, Ridge KM, Pedemonte C, Bertorello AM, Sznajder JI. Hypoxia-induced endocytosis of Na, K-ATPase in alveolar epithelial cells is mediated by mitochondrial reactive oxygen species and PKC-_. J Clin Invest. 2003;111:1057-64.

56. Wodopia R, Ko HS, Billian J, Wiesner R, Bartsch P, Mairbaurl H. Hypoxia decreases proteins involved in epithelial electrolyte transport in A549 cells and rat lung. Am J Physiol Lung Cell Mol Physiol. 2000;279:L1110-9.

57. Ballinger MN, Newstead MW, Zeng X, Bhan U, Horowitz JC, Moore $\mathrm{BB}$, et al. TLR signaling prevents hyperoxia-induced lung injury by protecting the alveolar epithelium from oxidantmediated death. J Immunol. 2012;189: 356-64.

58. Kallet RH, Matthay MA. Hyperoxic acute lung injury. Respir Care. 2013;58:123-41.

59. Kolliputi N, Shaik RS, Waxman AB. The inflammasome mediates hyperoxia-induced alveolar cell permeability. J Immunol. 2010;184:5819-26.

60. Beitler JR, Hubmayr RD, Malhotra A. Cross talk opposing view: there is not added benefit to providing permissive hypercapnia in the treatment of ARDS. J Physiol. 2013;591:2767-9.

61. Curley GF, Laffey JG, Kavanagh BP. Cross talk proposal: there is added benefit to providing permissive hypercapnia in the treatment of ARDS. J Physiol. 2013;591:2763-5.

62. Vadasz I, Hubmayr RD, Nin N, Sporn PH, Sznajder JI. Hypercapnia: a nonpermissive environment for the lung. Am J Respir Cell Mol Biol. 2012;46:417-21.

63. Helenius IT, Krupinski T, Turnbull DW, Gruenbaum Y, Silverman N, Johnson EA. Elevated CO2 suppresses specific Drosophila innate immune responses and resistance to bacterial infection. Proc Natl Acad Sci USA. 2009;106:18710-5.

64. Wang N, Gates KL, Trejo H, Favoreto S Jr, Schleimer RP, Sznajder JI, Beitel GJ, Sporn PH. Elevated CO2 selectively inhibits interleukin-6 and tumor necrosis factor expression and decreases phagocytosis in the macrophage. FASEB J. 2010;24:217890.

65. Vadasz I, Dada LA, Briva A, Helenius IT, Sharabi K, Welch LC, et al. Evolutionary conserved role of c-Jun-N terminal kinase in CO2-induced epithelial dysfunction. PloS One. 2012;7:e46696.

66. Vadasz I, Dada LA, Briva A, Trejo HE, Welch LC, Chen J, et al. AMP-activated protein kinase regulates $\mathrm{CO} 2$-induced alveolar epithelial dysfunction in rats and human cells by promoting $\mathrm{Na}$, KATPase endocytosis. J Clin Invest. 2008;118:752-62.

67. Briva A, Vadasz I, Lecuona E, Welch LC, Chen J, Dada LA. High $\mathrm{CO}_{2}$ levels impair alveolar epithelial function independently of pH. PloS One. 2007;2:e1238. 
68. Gates KL, Howell HA, Nair A, Vohwinkel CU, Welch LC, Beitel GJ, Hauser AR, Sznajder JI, Sporn PH. Hypercapnia impairs lung neutrophil function and increases mortality in murine pseudomonas pneumonia. Am J Respir Cell Mol Biol. 2013.

69. Kuebler WM. The Janus-faced regulation of endothelial permeability by cyclic GMP. Am J Physiol Lung Cell Mol Physiol. 2011;301:L157-60.

70. Balch WE, Morimoto RI, Dillin A, Kelly JW. Adapting proteostasis for disease intervention. Science. 2008;319:916-9.

71. Vadasz I, Weiss CH, Sznajder JI. Ubiquitination and proteolysis in acute lung injury. Chest. 2012;141:763-71.

72. Eldridge L, Moldobaeva A, Wagner EM. Increased hyaluronan fragmentation during pulmonary ischemia. Am J Physiol Lung Cell Mol Physiol 2011;301:L782-8.

73. Bachmaier K, Toya S, Gao X, Triantafillou T, Garrean S, Park $\mathrm{GY}$, et al. E3 ubiquitin ligase Cblb regulates the acute inflammatory response underlying lung injury. Nat Med. 2007;13:920-6.

74. Traweger A, Fang D, Liu YC, Stelzhammer W, Krizbai IA, Fresser $\mathrm{F}$, et al. The tight junction-specific protein occludin is a functional target of the E3 ubiquitin-protein ligase itch. J Biol Chem. 2002;277:10201-8.

75. Helenius IT, Dada LA, Sznajder JI. Role of ubiquitination in $\mathrm{Na}$, KATPase regulation during lung injury. Proc Am Thorac Soc. 2010;7:65-70.

76. Staub O, Rotin D. Role of ubiquitylation in cellular membrane transport. Physiol Rev. 2006;86:669-707.

77. Mutlu GM, Budinger GR, Wu M, Lam AP, Zirk A, Rivera S, et al. Proteasomal inhibition after injury prevents fibrosis by modulating TGF-_1 signalling. Thorax. 2012;67:139-46.

78. Vohwinkel CU, Lecuona E, Sun H, Sommer N, Vadasz I, Chandel NS, Sznajder JI. Elevated CO2 levels cause mitochondrial dysfunction and impair cell proliferation. J Biol Chem. 2011;286:37067-76.

79. Chouteau JM, Obiako B, Gorodnya OM, Pastukh VM, Ruchko MV, Wright AJ, et al. Mitochondrial DNA integrity may be a determinant of endothelial barrier properties in oxidantchallenged rat lungs. Am J Physiol Lung Cell Mol Physiol. 2011;301:L892-98.

80. Thomas KC, Roberts JK, Deering-Rice CE, Romero EG, Dull RO, Lee J, et al. Contributions of TRPV1, endovanilloids, and endoplasmic reticulum stress in lung cell death in vitro and lung injury. Am J Physiol Lung Cell Mol Physiol. 2012;302:L111-9.

81. Koval M. Claudin heterogeneity and control of lung tight junctions. Ann Rev Physiol. 2013;75:551-67.

82. Burnham EL, McCord JM, Bose S, Brown LA, House R, Moss M, Gaydos J. Protandim does not influence alveolar epithelial permeability or intrapulmonary oxidative stress in human subjects with alcohol use disorders. Am J Physiol Lung Cell Mol Physiol. 2012;302:L688-99.

83. Olson N, Hristova M, Heintz NH, Lounsbury KM, van der Vliet A. Activation of hypoxia-inducible factor-1 protects airway epithelium against oxidant-induced barrier dysfunction. Am J Physiol Lung Cell Mol Physiol. 2011;301:L993-1002.

84. Overgaard CE, Daugherty BL, Mitchell LA, Koval M. Claudins: control of barrier function and regulation in response to oxidant stress. Antioxid Redox Signal. 2011;15:1179-93.

85. Shi JX, Su X, Xu J, Zhang WY, Shi Y. MK2 posttranscriptionally regulates TNF-_-induced expression of ICAM-1 and IL-8 via tristetraprolin in human pulmonary microvascular endothelial cells. Am J Physiol Lung Cell Mol Physiol. 2012;302:L793-9.

86. Terakado M, Gon Y, Sekiyama A, Takeshita I, Kozu Y, Matsumoto K, et al. The Rac1/JNK pathway is critical for EGFRdependent barrier formation in human airway epithelial cells. AmJ Physiol Lung Cell Mol Physiol. 2011;300:L56-63.

87. Vandenbroucke E, Mehta D, Minshall R, Malik AB. Regulation of endothelial junctional permeability. Ann NY Acad Sci. 2008;1123:134-45.

88. Dudek SM, Garcia JG. Cytoskeletal regulation of pulmonary vascular permeability. J Appl Physiol. 2001;91:1487-500.

89. Mehta D, Malik AB. Signaling mechanisms regulating endothelial permeability. Physiol Rev. 2006;86:279-367.

90. Ochoa CD, Stevens T. Studies on the cell biology of interendothelial cell gaps. Am J Physiol Lung Cell Mol Physiol. 2012;302:L275-86.

91. Losa D, Chanson M, Crespin S. Connexins as therapeutic targets in lung disease. Expert Opin Ther Targets. 2011;15:9891002.

92. Wang L, Yin J, Nickles HT, Ranke H, Tabuchi A, Hoffmann $\mathrm{J}$, et al. Hypoxic pulmonary vasoconstriction requires connexin 40-mediated endothelial signal conduction. J Clin Invest. 2012;122:4218-30.

93. Parthasarathi K, Ichimura H, Monma E, Lindert J, Quadri S, Issekutz A, et al. Connexin 43 mediates spread of Ca2-dependent proinflammatory responses in lung capillaries. J Clin Invest. 2006;116:2193-200.

94. Parthasarathi K. Endothelial connexin43 mediates acid-induced increases in pulmonary microvascular permeability. Am J Physiol Lung Cell Mol Physiol. 2012;303:L33-42.

95. Collins SR, Blank RS, Deatherage LS, Dull RO. The endothelial glycocalyx: emerging concepts in pulmonary edema and acute lung injury. Anesth Analg. 2013;117:664-74.

96. Job KM, Dull RO, Hlady V. Use of reflectance interference contrast microscopy to characterize the endothelial glycocalyx stiffness. Am J Physiol Lung Cell Mol Physiol. 2012;302:L124249.

97. Dull RO, Cluff M, Kingston J, Hill D, Chen H, Hoehne S, et al. Lung heparan sulfates modulate $\mathrm{K}(\mathrm{fc})$ during increased vascular pressure: evidence for glycocalyx-mediated mechanotransduction. Am J Physiol Lung Cell Mol Physiol. 2012;302:L816-28.

98. Zebda N, Dubrovskyi O, Birukov KG. Focal adhesion kinase regulation of mechanotransduction and its impact on endothelial cell functions. Microvasc Res. 2012;83:71-81. 
99. Lu Q, Sakhatskyy P, Grinnell K, Newton J, Ortiz M, Wang Y, et al. Cigarette smoke causes lung vascular barrier dysfunction via oxidative stress-mediated inhibition of RhoA and focal adhesion kinase. Am J Physiol Lung Cell Mol Physiol. 2011301: L847-57.

100. Ware LB, Matthay MA. The acute respiratory distress syndrome. N Engl J Med. 2000;342:1334-49.

101. Ware LB, Matthay MA. Alveolar fluid clearance is impaired in the majority of patients with acute lung injury and the acute respiratory distress syndrome. Am J Respir Crit Care Med. 2001;163:1376-83.

102. Goodson P, Kumar A, Jain L, Kundu K, Murthy N, Koval M, Helms MN. Nadph oxidase regulates alveolar epithelial sodium channel activity and lung fluid balance in vivo via O2 signaling. Am J Physiol Lung Cell Mol Physiol. 2012;302:L410-9.

103. Gusarova GA, Trejo HE, Dada LA, Briva A, Welch LC, Hamanaka RB, et al. Hypoxia leads to Na, K-ATPase downregulation via $\mathrm{Ca} 2$ _elease-activated $\mathrm{Ca} 2$ _ channels and AMPK activation. Mol Cell Biol. 2011;31:3546-56.

104. Kooijman EE, Kuzenko SR, Gong D, Best MD, Folkesson HG. Phosphatidylinositol 4,5-bisphosphate stimulates alveolar epithelial fluid clearance in male and female adult rats. Am J Physiol Lung Cell Mol Physiol. 2011;301:L804-11.

105. Lei J, Ingbar DH. Src kinase integrates PI3K/Akt and MAPK/ ERK1/2 pathways in T3-induced Na-K-ATPase activity in adult rat alveolar cells. Am J Physiol Lung Cell Mol Physiol. 2011;301:L765-71.

106. Soukup B, Benjamin A, Orogo-Wenn M, Walters D. Physiological effect of protein kinase $\mathrm{C}$ on $\mathrm{ENaC}$-mediated lung liquid regulation in the adult rat lung. Am J Physiol Lung Cell Mol Physiol. 2012;302:L133-9.

107. Zhao KQ, Xiong G, Wilber M, Cohen NA, Kreindler JL. A role for two-pore $\mathrm{K}_{-}$channels in modulating $\mathrm{Na}$ _absorption and $\mathrm{Cl}$ _secretion in normal human bronchial epithelial cells. Am J Physiol Lung Cell Mol Physiol. 2012;302:L4-12.

108. Rajasekaran SA, Palmer LG, Moon SY, Peralta Soler A, Apodaca GL, Harper JF. Na,K-ATPase activity is required for formation of tight junctions, desmosomes, and induction of polarity in epithelial cells. Mol Biol Cell. 2001;12:3717-32.

109. Rajasekaran SA, Palmer LG, Quan K, Harper JF, Ball WJ $\mathrm{Jr}$, Bander NH, et al. Na,K-ATPase _-subunit is required for epithelial polarization, suppression of invasion, and cell motility. Mol Biol Cell. 2001;12:279-95.

110. Vagin O, Dada LA, Tokhtaeva E, Sachs G. The Na-K-ATPase _1_1 heterodimer as a cell adhesion molecule in epithelia. Am $\bar{J}$ Physiol Cell Physiol. 2012;302:C1271-81.

111. Marshall RP, Bellingan G, Webb S, Puddicombe A, Goldsack N, McAnulty RJ, Laurent GJ. Fibroproliferation occurs early in the acute respiratory distress syndrome and impacts on outcome. Am J Respir Crit Care Med. 2000;162:1783-8.

112. Calfee CS, Ware LB, Eisner MD, Parsons PE, Thompson BT, Wickersham N, et al, NHLBI ARDS Network. Plasma recep- tor for advanced glycation end products and clinical outcomes in acute lung injury. Thorax. 2008;63:1083-9.

113. Guo WA, Knight PR, Raghavendran K. The receptor for advanced glycation end products and acute lung injury/acute respiratory distress syndrome. Intensive Care Med. 2012;38:1588-98.

114. Hergrueter AH, Nguyen K, Owen CA. Matrix metalloproteinases: all the RAGE in the acute respiratory distress syndrome. Am J Physiol Lung Cell Mol Physiol. 2011;300:L512-5.

115. Yamakawa N, Uchida T, Matthay MA, Makita K. Proteolytic release of the receptor for advanced glycation end products from in vitro and in situ alveolar epithelial cells. Am J Physiol Lung Cell Mol Physiol. 2011;300:L516-25.

116. Buckley ST, Medina C, Kasper M, Ehrhardt C. Interplay between RAGE, CD44, and focal adhesion molecules in epithelial-mesenchymal transition of alveolar epithelial cells. Am J Physiol Lung Cell Mol Physiol. 2011;300:L548-59.

117. Bdeir K, Higaz AR, Kulikovskaya I, Christofidou-Solomidou M, Vinogradov S. Neutrophil $\alpha$-defensins cause lung injury by disrupting the capillary-epithelial barrier. Am J Respir Crit Care Med. 2010;181:935-46.

118. Rezaee F, Georas S. New insights into airway epithelial barrier function in health and disease. Am J Respir Cell Mol Biol. 2014;50:857-69.

119. Godfrey RW, Severs NJ, Jeffery PK. Freeze-fracture morphology and quantification of human bronchial epithelial tight junctions. Am J Respir Cell Mol Biol. 1992;6:453-8.

120. Vermeer PD, Einwalter LA, Moninger TO, Rokhlina T, Kern JA, Zabner J, et al. Segregation of receptor and ligand regulates activation of epithelial growth factor receptor. Nature. 2003;422:322-6.

121. Sidhaye VK, Chau E, Breysse PN, King LS. Septin-2 mediates airway epithelial barrier function in physiologic and pathologic conditions. Am J Respir Cell Mol Biol. 2011;45:120-6.

122. Stevenson BR, Anderson JM, Goodenough DA, Mooseker MS. Tight junction structure and $\mathrm{ZO}-1$ content are identical in two strains of Madin-Darby canine kidney cells which differ in transepithelial resistance. J Cell Biol. 1988;107:2401-8.

123. Benais-Pont G, Punn A, Flores-Maldonado C, Eckert J, Raposo G, Fleming TP, et al. Identification of a tight junctionassociated guanine nucleotide exchange factor that activates Rho and regulates paracellular permeability. J Cell Biol. 2003;160:729-40.

124. Schulzke JD, Fromm M. Tight junctions: molecular structure meets function. Ann N Y Acad Sci. 2009;1165:1-6.

125. Niessen CM, Gottardi CJ. Molecular components of the adherens junction. Biochim Biophys Acta. 2008;1778:562-71.

126. Furuse M, Fujita K, Hiiragi T, Fujimoto K, Tsukita S. Claudin-1 and -2: novel integral membrane proteins localizing at tight junctions with no sequence similarity to occludin. J Cell Biol. 1998;141:1539-50.

127. Coyne CB, Gambling TM, Boucher RC, Carson JL, Johnson 
LG. Role of claudin interactions in airway tight junctional permeability. Am J Physiol Lung Cell Mol Physiol. 2003;285:L1166-78.

128. Ohta H, Chiba S, Ebina M, Furuse M, Nukiwa T. Altered expression of tight junction molecules in alveolar septa in lung injury and fibrosis. Am J Physiol Lung Cell Mol Physiol. 2012;302:L193-205.

129. Kaarteenaho-Wiik R, Soini Y. Claudin-1, -2, -3, -4, -5, and -7 in usual interstitial pneumonia and sarcoidosis. J Histochem Cytochem. 2009;57:187-95.

130. Mitchell LA, Overgaard CE, Ward C, Margulies SS, Koval M. Differential effects of claudin-3 and claudin-4 on alveolar epithelial barrier function. Am J Physiol Lung Cell Mol Physiol. 2011;301:L40-9.

131. Sonoda N, Furuse M, Sasaki H, Yonemura S, Katahira J, Horiguchi $\mathrm{Y}$, et al. Clostridium perfringens enterotoxin fragment removes specific claudins from tight junction strands: evidence for direct involvement of claudins in tight junction barrier. J Cell Biol. 1999;147:195-204.

132. Coyne CB, Vanhook MK, Gambling TM, Carson JL, Boucher RC, Johnson LG. Regulation of airway tight junctions by proinflammatory cytokines. Mol Biol Cell. 2002;13:3218-34.

133. Armstrong SM, Wang C, Tigdi J, Si X, Dumpit C, Charles S, et al. Influenza infects lung microvascular endothelium leading to microvascular leak: role of apoptosis and claudin-5. PLoS ONE 2012;7:e47323.

134. Koval M. Claudin heterogeneity and control of lung tight junctions. Ann Rev Physiol. 2013;75:551-67.

135. Furuse M, Hirase T, Itoh M, Nagafuchi A, Yonemura S, Tsukita S, et al. Occludin: a novel integral membrane protein localizing tight junctions. J Cell Biol. 1993;123:1777-88.

136. Sonoda N, Furuse M, Sasaki H, Yonemura S, Katahira J, Horiguchi $\mathrm{Y}$, et al. Clostridium perfringens enterotoxin fragment removes specific claudins from tight junction strands: evidence for direct involvement of claudins in tight junction barrier. J Cell Biol. 1999;147:195-204.

137. Van Itallie CM, Fanning AS, Holmes J, Anderson JM. Occludin is required for cytokine-induced regulation of tight junction barriers. J Cell Sci 2010;123:2844-52.

138. Huber D, Balda MS, Matter K. Occludin modulates transepithelial migration of neutrophils. J Biol Chem. 2000;275:5773-8.

139. Stevenson BR, Siliciano JD, Mooseker MS, Goodenough DA. Identification of ZO-1: a high molecular weight polypeptide associated with the tight junction (zonula occludens) in a variety of epithelia. J Cell Biol. 1986;103:755-66.

140. González-Mariscal L, Betanzos A, Avila-Flores A. MAGUK proteins: structure and role in the tight junction. Semin Cell Dev Biol. 2000;11:315-24.

141. Fanning AS, Anderson JM. Zonula occludens- 1 and -2 are cytosolic scaffolds that regulate the assembly of cellular junctions. Ann N Y Acad Sci. 2009;1165:113-20.

142. Jesaitis LA, Goodenough DA. Molecular characterization and tissue distribution of $\mathrm{ZO}-2$, a tight junction protein homologous to ZO-1 and the Drosophila discs-large tumor suppressor protein. J Cell Biol. 1994;124:949-61.

143. Haskins J, Gu L, Wittchen ES, Hibbard J, Stevenson BR. ZO-3, a novel member of the MAGUK protein family found at the tight junction, interacts with ZO-1 and occludin. J Cell Biol. 1998;141:199-208.

144. Betanzos A, Huerta M, Lopez-Bayghen E, Azuara E, Amerena J, González-Mariscal L. The tight junction protein ZO-2 associates with Jun, Fos and C/EBP transcription factors in epithelial cells. Exp Cell Res. 2004;292:51-66.

145. Katsuno T, Umeda K, Matsui T, Hata M, Tamura A, Itoh M, et al. Deficiency of zonula occludens- 1 causes embryonic lethal phenotype associated with defected yolk sac angiogenesis and apoptosis of embryonic cells. Mol Biol Cell. 2008;19:2465-75.

146. Adachi M, Inoko A, Hata M, Furuse K, Umeda K, Itoh M, et al. Normal establishment of epithelial tight junctions in mice and cultured cells lacking expression of ZO-3, a tight-junction MAGUK protein. Mol Cell Biol. 2006;26:9003-15.

147. Ohkuni T, Kojima T, Ogasawara N, Masaki T, Ninomiya T, Kikuchi S, et al. Expression and localization of tricellulin in human nasal epithelial cells in vivo and in vitro. Med Mol Morphol. 2009;42:204-11.

148. Excoffon KJ, Guglielmi KM, Wetzel JD, Gansemer ND, Campbell JA, Dermody TS, et al. Reovirus preferentially infects the basolateral surface and is released from the apical surface of polarized human respiratory epithelial cells. J Infect Dis. 2008;197:1189-97.

149. Wang Q, Margolis B. Apical junctional complexes and cell polarity. Kidney Int. 2007;72:1448-58.

150. Price CJ, Brindle NP. Vasodilator-stimulated phosphoprotein is involved in stress-fiber and membrane ruffle formation in endothelial cells. Arterioscler Thromb Vasc Biol. 2000;20:2051-6.

151. Furman C, Sieminski AL, Kwiatkowski AV, Rubinson DA, Vasile E, Bronson RT, et al. Ena/VASP is required for endothelial barrier function in vivo. J Cell Biol. 2007;179:761-75.

152. Henes J, Schmit M. Inflammation-associated repression of vasodilator-stimulated phosphoprotein (VASP) reduces alveolarcapillary barrier function during acute lung injury. FASEB J. 2009:23:4244-55. 